\title{
Funkcje słuchowe u osób śpiewających w chórze
} Auditory functions in choir singers

\section{Karolina Dajos, Zdzisław Marek Kurkowski}

Uniwersytet Marii Curie-Skłodowskiej, Lublin

Adres autora: Uniwersytet Marii Curie-Skłodowskiej, ul. Sowińskiego 17, 20-040 Lublin

\section{Streszczenie}

Głównym celem niniejszej pracy było zbadanie centralnych funkcji słuchowych u osób dorosłych śpiewających w chórze oraz ukazanie, że osoby te nie mają trudności w zakresie przetwarzania wysokości, głośności oraz czasu trwania dźwięków.

\begin{abstract}
W badaniu uczestniczyło 38 osób, podzielonych na dwie grupy: badawczą (23 osoby) i kontrolną (15 osób). W grupie badawczej znaleźli się członkowie amatorskiego chóru mieszanego, natomiast grupę kontrolną stanowiły osoby nigdy nie śpiewające $w$ chórze.
\end{abstract}

W niniejszej pracy wykorzystano następujące techniki badawcze: ankieta, którą wypełniali wszyscy badani przed rozpoczęciem innych badań; audiometria tonalna, w celu oceny czułości słuchu u poszczególnych osób; testy centralnych funkcji słuchowych DLI, DLF, DLD, oceniające progi dyskryminacji zmian głośności, wysokości i czasu trwania dźwięków.

Przeprowadzone badania potwierdziły, iż śpiew korzystnie wpływa na centralne funkcje słuchowe. Grupa badawcza osiągnęła lepsze wyniki badań centralnych funkcji słuchowych, niż grupa kontrolna. Oznacza to, iż osoby śpiewające w chórze są w stanie dostrzec mniejsze różnice pomiędzy dwoma dźwiękami, niż osoby z grupy kontrolnej. Szczególnie dużą różnicę można zaobserwować w przypadku dyskryminacji zmian wysokości dźwięku.

słowa kluczowe: śpiew • centralne funkcje słuchowe $\bullet$ DLF • DLI • DLD

\begin{abstract}
Main objective of this study was to examine central auditory functions in adult choir singers and to reveal that these subjects do not have any problems with sound pitch, loudness and duration processing.
\end{abstract}

Study includes 38 particiants, divided in 2 groups - examination (23) and control (15). Examination group consisted of amateur mixed choir singers and the control group included subjects who never sung a choir.

Following research tools were used in the study: a questionnaire, filled in by all participants of the study before the other tests, pure-tone audiometry - to assess sensitivity of hearing, central auditory functions tests DLI, DLF, DLD, that determine discrimination thresholds of volume, pitch and duration of sounds.

Research confirmed that singing favourably affects central auditory functions. The examination group had better results of central auditory functions examination than control group. It means that choir singers are able to determine small differences between sounds. Especially significant differences between these two groups occur in cases of pitch discrimination.

key words: singing • central auditory functions $\bullet$ DLF $\bullet$ DLI $\bullet$ DLD

\section{Wstęp}

Nie ulega wątpliwości, że muzyka wywiera wpływ na różne aspekty życia i osobowości każdego człowieka, niezależnie od tego, czy i w jakim stopniu ukształtowane są jego osobnicze zdolności muzyczne.
Badania psychologów muzyki oraz fizjologów pokazują, że muzyka może powodować szereg reakcji fizjologicznych organizmu. K. Steiner uważał muzykę za zjawisko fizyczne, które swoją częstotliwością lub natężeniem może oddziaływać na cały organizm ludzki [za: Bukowska, 2010].

W czasie słuchania muzyki dochodzi do określonych zmian w czynnościach organizmu: wzmożenia ciśnienia 
krwi, przyspieszenia oddechu, zwiększenia siły i szybkości pulsu, podwyższenia napięcia mięśniowego, wzrostu wydzielania wewnętrznego. Każdy organizm posiada pewne swoiste cechy, reakcje na muzykę mogą więc być odmienne i o różnym nasileniu [Wierszyłowski, 1968].

Nie ulega wątpliwości, że zarówno słuchanie, jak i wykonywanie muzyki ma ogromny wpływ na emocje człowieka. Aktywność muzyczna jest bowiem jednym z najbardziej naturalnych sposobów wyrażania uczuć i przeżyć.

Różne reakcje emocjonalne obserwowane podczas słuchania muzyki są prawdopodobnie wywoływane stymulacją wydzielania hormonów zwanych endorfinami oraz ich oddziaływaniem na twór siatkowaty [Bukowska A.]. Powołując się na badania wykorzystujące techniki neuroobrazowania można stwierdzić, że człowiek słuchający utworu, który subiektywnie ocenia jako przyjemny, zadowolenie to "przeżywa” także na poziomie neurofizjologicznym - w mózgu wytwarza się większa ilość substancji nazywanych opioidami (których działanie zbliżone jest do oddziaływania morfiny), wzrasta także aktywność struktur mózgowych uważanych za mózgowe ośrodki nagrody. Następuje również spadek poziomu hormonów kortykalnych aktywowanych w czasie przeżywania stresu. W trakcie słuchania utworów uznawanych za przyjemne u mężczyzn obserwuje się dodatkowo spadek poziomu testosteronu [Krukow, 2003].

Najprostszą, dostępną niemal wszystkim ludziom, formą ekspresji muzycznej jest śpiew. Ludzki głos powstaje jako wynik współdziałania aparatu fonacyjnego, oddechowego i artykulacyjnego. Śpiewanie nie pozostaje obojętne dla organizmu człowieka i jego psychiczno-organicznych odczuć - wpływa zarówno na fizyczną, jak i psychiczną sferę człowieka.

Śpiewanie wpływa na aparat oddechowy człowieka. Przy śpiewie niezbędny jest głęboki, dynamiczny oddech, z podparciem oddechowym. Oddech podczas śpiewania umożliwia człowiekowi wzmocnienie mięśni oddechowych - przepony, mięśni brzucha, grzbietu oraz mięśni międzyżebrowych. Istnieją badania wskazujące na pozytywny wpływ śpiewania na funkcje oddechowe u pacjentów z COPD (chronic obstructive pulmonary disease) [Bonilha i wsp. 2009]. Usprawnienie oddechu powoduje lepszą pracę układu krążenia. Pogłębiony, spokojny oddech pozwala na zredukowanie napięć fizycznych (np. usztywnienia mięśni) wynikających z codziennych sytuacji stresowych, a także osiągnięcie odprężenia psychicznego organizmu. Badania [Kreutz i wsp. 2004] wskazują, że śpiewanie powoduje znaczne podwyższenie pozytywnych i obniżenie negatywnych emocji.

Podczas śpiewu człowiek rozwija i wzmacnia aparat głosowy, ćwiczy i uelastycznia mięśnie mimiczne twarzy głównie warg i policzków.

Szczególnie pozytywne efekty śpiewania obserwuje się $\mathrm{w}$ populacji ludzi starszych, $\mathrm{z}$ różnego rodzaju schorzeniami, zaburzeniami pamięci, deficytami poznawczymi. Szczególnie dobrą metodą aktywizująca umysłowo ludzi starszych są próby śpiewania utworów z pamięci - pomaga to w skupieniu uwagi, usprawnia koncentrację i pamięć, pozytywnie wpływa na samoocenę [Gulińska-Grzeluszka, 2008].
Muzykoterapeuci, psycholodzy, pedagodzy zwracają uwagę na szczególny wpływ muzyki i śpiewu na rozwój dziecka. Śpiewanie jest podstawową formą muzycznej ekspresji dziecka. Piosenki dziecięce są krótkie, o prostej melodii i miarowym rytmie, dlatego też są dla dziecka łatwe do zapamiętania i odtworzenia. Śpiewając dziecko doskonali swój głos, wzmacnia narządy mowy oraz funkcjonowanie układu oddechowego. Śpiew umożliwia dziecku wyrażenie siebie, przekazanie swoich odczuć i myśli innym ludziom.

Śpiewanie nierozerwalnie wiąże się ze słuchem. Prawidłowy rozwój głosu człowieka jest bowiem uzależniony od funkcjonowania narządu słuchu - słuch pozwala na autokontrolę słuchową, zarówno podczas mowy, jak i podczas śpiewania [Tomatis, 1995].

\section{Metoda badania}

\section{Uczestnicy}

W badaniu uczestniczyło łącznie 38 osób, podzielonych na dwie grupy: badawczą i kontrolną.

W grupie badawczej było 23 członków amatorskiego chóru mieszanego, w tym 13 mężczyzn i 10 kobiet w wieku od 16 do 67 lat. Okres uczestniczenia w zajęciach chóralnych wynosił od 2 do 30 lat, średnio 13 lat. Dwie osoby posiadały wykształcenie muzyczne na poziomie szkoły muzycznej I stopnia. Na repertuar chóru składają się: chorały gregoriańskie, muzyka dawna (utwory pochodzące ze średniowiecza, renesansu i baroku), tzw. utwory polifoniczne, utwory ludowe. Próby chóru odbywają się 1-2 razy w tygodniu, czasem poprzedzone są ćwiczeniami emisji głosu. Dodatkowo 7 osób z grupy badawczej uczęszcza lub uczęszczało na regularne zajęcia emisji głosu.

Grupę kontrolną stanowiło 15 zdrowych osób w wieku od 24 do 68 lat, które nigdy nie śpiewały w chórze. Dwie osoby z grupy kontrolnej uczestniczyły w przeszłości w zajęciach emisji głosu.

\section{Techniki badania}

Przed rozpoczęciem badań każdy uczestnik wypełnił ankietę składającą się z 25 pytań podzielonych na 3 kategorie. Pierwsza część ankiety dotyczyła zagadnień związanych ze słuchem. Pytania dotyczyły między innymi subiektywnej oceny stanu słuchu, występowania zaburzeń słyszenia lub chorób uszu, występowania szumów usznych bądź nadwrażliwości słuchowej. Druga część zawierała pytania dotyczące głosu - występowania zaburzeń głosu oraz infekcji górnych dróg oddechowych. Trzecią część ankiety stanowiły pytania dotyczące uczestnictwa w zajęciach chóralnych i zajęciach emisji głosu.

Po wypełnieniu ankiety każdy uczestnik miał wykonywane cztery badania: audiometrię tonalną progową, test DLD, test DLF, test DLI. Badanie audiometrii tonalnej wykonane zostało za pomocą audiometru z Platformy Badań Zmysłów. Wykonywano badanie przewodnictwa powietrznego dla częstotliwości od 125 do $8000 \mathrm{~Hz}$ oddzielnie dla lewego i prawego ucha. Testy DLD, DLF, DLI zostały wykonane za pomocą programu komputerowego Auditory Processing Disorder (APD). Testy te były przeprowadzone metodą 
adaptacyjną. Test DLF pozwala na określenie progu dyskryminacji zmian wysokości dźwięku. Bodźcem dźwiękowym w badaniu DLF był ton prezentowany na poziomie 50 dB SL. Bodźcem standardowym był ton o częstotliwości $1000 \mathrm{~Hz}$, natomiast bodźcem wyróżnionym ton o niższej częstotliwości. Zadaniem badanego była reakcja na bodziec wyróżniony. Za pomocą testu DLI określa się próg dyskryminacji głośności dźwięku. Bodźcem akustycznym w tym badaniu był czysty ton o częstotliwości $1000 \mathrm{~Hz}$. Bodziec standardowy stanowił dźwięk o natężeniu $50 \mathrm{~dB}$, zaś bodziec wyróżniony ton o odpowiednio niższym natężeniu. Zadaniem badanego było zareagowanie na bodziec wyróżniony. Test DLD pozwala na uzyskanie progu dyskryminacji czasu trwania dźwięku. W tym przypadku bodźcem dźwiękowym był ton o częstotliwości $1000 \mathrm{~Hz}$ prezentowany na poziomie $50 \mathrm{~dB}$ SL. Bodziec standardowy to ton o czasie trwania $500 \mathrm{~ms}$, bodziec wyróżniony to ton o odpowiednio krótszym czasie trwania. Zadaniem badanego była reakcja na ton wyróżniony. Badania u poszczególnych uczestników odbywały się w podobnych warunkach akustycznych, o mniej więcej tej samej porze (w godzinach wieczornych).

\section{Wyniki}

Ankieta

Większość osób badanych nie stwierdza u siebie trudności w słyszeniu, jedynie 5,3\% wszystkich badanych uważa, że ma problemy ze słuchem. Liczba ta zwiększa się, gdy w środowisku występuje hałas - w takim wypadku na problemy ze słyszeniem wskazuje $44,7 \%$ wszystkich badanych. Jedna czwarta wszystkich osób badanych w ciągu ostatnich kilku lat była leczona z powodu chorób uszu (głównie z powodu zapalenia ucha). Niemal 30\% wszystkich badanych stwierdza u siebie występowanie szumów usznych sporadycznie, w sytuacjach narażenia na hałas lub przemęczenia organizmu.

89,5\% wszystkich badanych słucha na co dzień muzyki (różnego rodzaju) zwykle ok. 1-4 godzin dziennie.

Na występowanie dolegliwości związanych z pracą głosem, utrzymujących się od kilku minut do kilku dni, zwraca uwagę 9 osób spośród wszystkich badanych, w tym aż 8 osób z grupy badawczej. Najczęściej wskazywanymi objawami są występujące po dużym wysiłku głosowym chrypka, zmiana barwy głosu, ból gardła. Jeśli chodzi o infekcje górnych dróg oddechowych, ponad połowa wszystkich badanych zapada na nie rzadko (kilka razy w roku), zwykle są to drobne przeziębienia lub zapalenia gardła.

Z uzyskanych danych wynika, iż ponad $75 \%$ wszystkich badanych śpiewa w domu w różnych sytuacjach (np. podczas lekkich prac domowych lub jazdy samochodem). Większości badanych (niemal 70\%) podczas śpiewu zdarza się „fałszować”, czyli zaśpiewać dźwięk inny niż oczekiwany. Jednocześnie znaczna większość badanych słyszy, kiedy sami fałszują $(71,1 \%)$ oraz kiedy fałszują inni $(78,9 \%)$.

\section{Audiometria tonalna}

Wszystkie osoby uczestniczące $\mathrm{w}$ badaniu miały przeprowadzoną progową audiometrię tonalną za pomocą audiometru z Platformy Badań Zmysłów. Za jej pomocą wyznaczono średni próg słyszenia (na podstawie wyników dla częstotliwości 500, 1000 i $2000 \mathrm{~Hz}$ ) dla poszczególnych osób oraz dla całej grupy badanych.

W oparciu o klasyfikację BIAP można uznać, że większość osób z grupy badawczej ma słuch w normie, pomimo występowania u niektórych badanych lekkiego ubytku słuchu w jednym uchu. Tylko jedna osoba w grupie badawczej w obu uszach uzyskała wynik powyżej $20 \mathrm{~dB}$ (ucho lewe $25 \mathrm{~dB}$, ucho prawe $23 \mathrm{~dB}$ ). U kilku osób wartości progu są wyższe od $20 \mathrm{~dB}$, jednak tylko w jednym uchu. Średni ubytek słuchu w grupie badawczej wynosi $11 \mathrm{~dB}$ (średni ubytek słuchu dla ucha lewego w odniesieniu do całej grupy - $11 \mathrm{~dB}$, średni ubytek słuchu dla ucha prawego w odniesieniu do całej grupy $-11 \mathrm{~dB}$ ).

Podobnie w grupie kontrolnej - u jednej osoby można stwierdzić lekki ubytek słuchu (lewe ucho $23 \mathrm{~dB}$, prawe ucho $20 \mathrm{~dB}$ ). Pozostałe osoby mają prawidłowy próg słyszenia. Podobnie jak w grupie badawczej, średni próg słyszenia w grupie kontrolnej wynosi $11 \mathrm{~dB}$.

Powszechnie wiadomo, iż wraz z wiekiem próg słyszenia się obniża. Na podstawie wyników audiometrii tonalnej zauważyć można wysoką korelację między wynikiem badania a wiekiem osoby badanej, co przedstawia Rycina 1. W grupie badawczej najlepsze wyniki uzyskane zostały przez osoby w wieku 16-22, 25-26 oraz 31-54 lata. Podobną tendencję można zauważyć także w wypadku grupy kontrolnej.

\section{Testy centralnych funkcji słuchowych}

Progi dyskryminacji zmian czasu trwania dźwięków w grupie badawczej w teście DLD są zróżnicowane - zawierają się w przedziale 51,27 ms - 408,25 ms. Średni próg dyskryminacji czasu trwania dźwięku w całej grupie badawczej wynosi 176,22 ms. 12 osób uzyskało wyniki niższe niż 176,22 ms, natomiast 11 osób osiągnęło wyniki wyższe od średniej.

Średni próg dyskryminacji zmian wysokości dźwięku w grupie badawczej wynosi 20,96 Hz. 15 osób osiągnęło wyniki niższe od średniej, natomiast 8 osób uzyskało progi dyskryminacji wyższe od średniej. Wyniki testu DLF w grupie badawczej zawierają się w zakresie od 5,88 $\mathrm{Hz}$ do $82,21 \mathrm{~Hz}$.

Wyniki uzyskane przez grupę badawczą w teście DLI mieszczą się w zakresie 1,5-4,06 dB. Średni próg dyskryminacji zmian natężenia dźwięku w grupie badawczej wynosi 2,86 dB. Wśród osób z grupy badawczej aż 16 osób osiągnęło wyniki niższe niż średni próg dla całej grupy, natomiast 7 osób ma wyniki wyższe od średniej.

Średni próg dyskryminacji zmian czasu trwania dźwięku w grupie kontrolnej wynosi 204,31 ms. Sześć osób uzyskało progi wyższe niż średnia dla całej grupy, zaś 9 osób osiągnęło wyniki niższe niż średni próg dyskryminacji czasu trwania dźwięku dla grupy kontrolnej. Wyniki uzyskane w teście DLD zawierają się w granicach 73,5-430,25 ms.

Wyniki uzyskane w badaniu DLF przez grupę kontrolną zawierają się w zakresie od 7,15 Hz do 190 Hz. Średni 


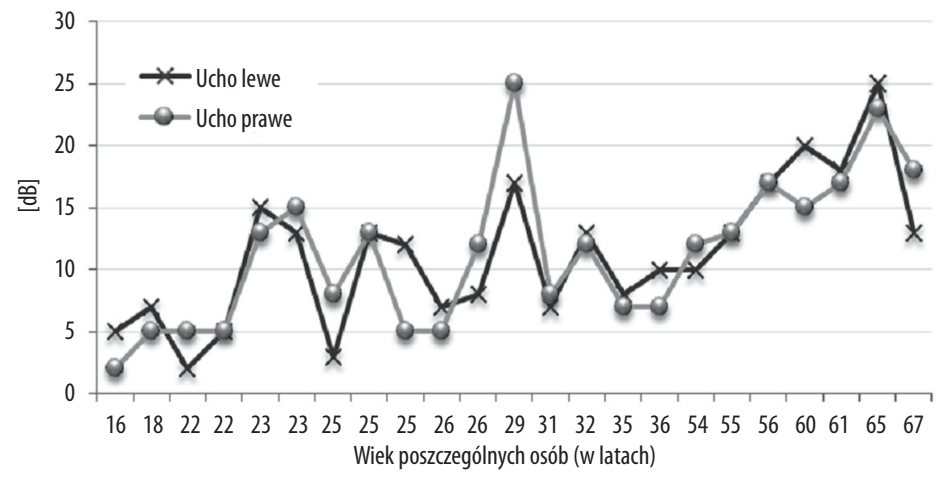

Rycina 1. Zależność średniego wyniku z audiometrii tonalnej dla ucha lewego i prawego od wieku badanych w grupie badawczej

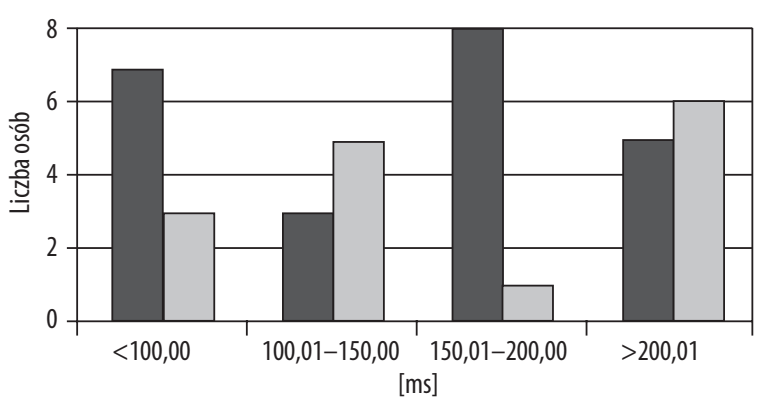

Rycina 2. Rozkład wyników testu DLD w grupie badawczej i kontrolnej

próg dyskryminacji wysokości w grupie kontrolnej wynosi $67,13 \mathrm{~Hz}$. Dziewięć osób z grupy kontrolnej uzyskało wyniki niższe od średniego progu, natomiast 6 osób uzyskało wyniki wyższe.

Średni próg dyskryminacji natężenia dźwięku w grupie kontrolnej wynosi 3,32 dB. Progi dyskryminacji natężenia dźwięku niższe niż wynik średni uzyskało 9 osób, natomiast wyższe 6 osób. Wyniki u poszczególnych osób w tym badaniu mieszczą się w przedziale od 1,5 do 5,31 dB.

Rozkład wyników testów DLD, DLF i DLI w obu grupach badanych przedstawiono na wyk. 2, 3, 4. Jeśli chodzi o test DLD: 10 osób (w tym $7 \mathrm{z}$ grupy badawczej i 3 z grupy kontrolnej) uzyskało bardzo dobry próg dyskryminacji zmian czasu trwania dźwięku - mniejszy bądź równy 100 ms. Wyniki w zakresie od 100,01 do 150,00 ms uzyskało 8 osób ( 3 z grupy badawczej, 5 z grupy kontrolnej), natomiast wyniki w granicach 150,01-200,00 ms - 9 osób (8 z grupy badawczej, $1 \mathrm{z}$ kontrolnej). Progi dyskryminacji poniżej 200 ms można uznać za bardzo dobre. 11 osób ( 5 z grupy badawczej, 6 z grupy kontrolnej) uzyskało wynik większy od 200,01 ms. Wyniki powyżej tej granicy są nieco słabsze, lecz nie oznaczają trudności w dyskryminacji czasu trwania dźwięku, a są prawdopodobnie wynikiem niedostatecznego zrozumienia zadania (Rycina 2).

Rozkład wyników testu DLF w obu grupach badawczych jest bardzo zróżnicowany. 6 osób spośród wszystkich badanych uzyskało wyniki niższe niż $10 \mathrm{~Hz}$ (w tym 5 osób $\mathrm{z}$ grupy badawczej oraz tylko 1 osoba $\mathrm{z}$ grupy kontrolnej). 11 osób (5 osób z grupy badawczej oraz 6 osób z grupy kontrolnej) osiągnęło progi dyskryminacji mieszczące się w zakresie 10,01-15,00 Hz. 14 osób uzyskało wyniki

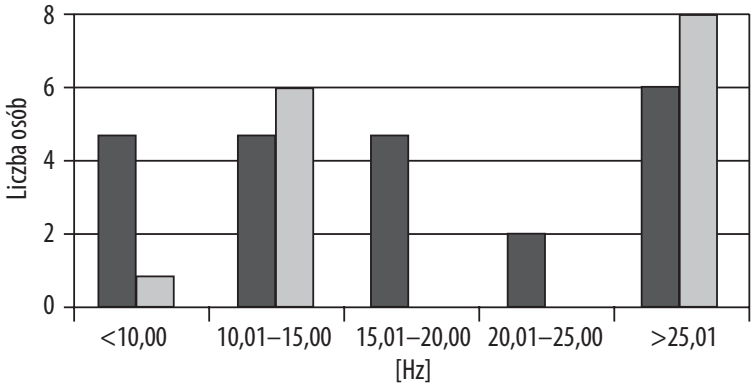

Rycina 3. Rozkład wyników testu DLF w grupie badawczej i kontrolnej

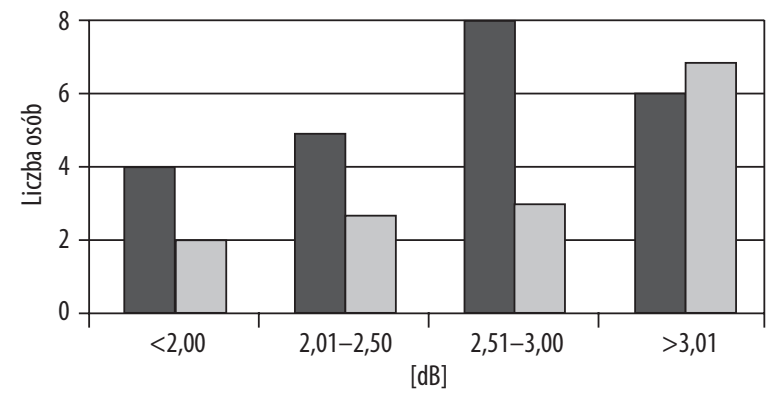

Rycina 4. Rozkład wyników testu DLI w grupie badawczej i kontrolnej

powyżej 25,01 Hz (w tym 6 osób z grupy badawczej i 8 osób z grupy kontrolnej). W grupie badawczej 5 osób osiągnęło progi dyskryminacji na poziomie $15,01-20,00 \mathrm{~Hz}$, zaś 2 osoby uzyskały wyniki w zakresie od 20,01 do 25,00 Hz. W grupie kontrolnej żadna osoba nie uzyskała wyników w tych granicach (Rycina 3).

Jeśli chodzi o test DLI: progi dyskryminacji niższe niż 2 dB wśród wszystkich badanych uzyskało 6 osób (4 osoby z grupy badawczej i 2 osoby z grupy kontrolnej). Osiem uzyskało wyniki w zakresie od 2,01 do 2,50 dB (5 osób z grupy badawczej i 3 osoby z grupy kontrolnej), zaś 11 osób w granicach od 2,51 dB do 3,00 dB. 13 osób osiągnęło wyniki wyższe niż 3,01 dB (6 osób z grupy badawczej i 7 z kontrolnej (Rycina 4).

W Tabeli 1 przedstawiono średnie progi dyskryminacji czasu trwania, wysokości oraz natężenia dźwięku w grupie badawczej oraz kontrolnej. Grupa badawcza we wszystkich trzech 
Tabela 1. Średnie wyniki badań DLD, DLF oraz DLI w grupie badawczej i kontrolnej

\begin{tabular}{cccc}
\hline & $\begin{array}{c}\text { Dyskryminacja czasu } \\
\text { trwania }[\mathrm{ms}]\end{array}$ & $\begin{array}{c}\text { Dyskryminacja wysokości } \\
{[\mathrm{Hz}]}\end{array}$ & $\begin{array}{c}\text { Dyskryminacja natężenia } \\
{[\mathbf{d B ]}]}\end{array}$ \\
\hline Grupa badawcza & 176,22 & 20,96 & 2,86 \\
\hline Grupa kontrolna & 204,31 & 67,13 & 3,32 \\
\hline Różnica & 28,09 & 46,17 & 0,46 \\
\hline
\end{tabular}

Tabela 2. Wyniki testów DLD, DLI i DLF uzyskane przez kobiety i mężczyzn z grupy badawczej i kontrolnej

\begin{tabular}{ccccccc}
\hline & \multicolumn{2}{c}{$\begin{array}{c}\text { Średni próg dyskryminacji czasu } \\
\text { trwania dźwięku [ms] }\end{array}$} & \multicolumn{2}{c}{$\begin{array}{c}\text { Średni próg dyskryminacji } \\
\text { wysokości dźwięku [Hz] }\end{array}$} & \multicolumn{2}{c}{$\begin{array}{c}\text { Średni próg dyskryminacji } \\
\text { natężenia dźwięku [dB] }\end{array}$} \\
\cline { 2 - 7 } & Kobiety & Mężczyźni & Kobiety & Mężczyźni & Kobiety & Mężczyźni \\
\hline $\begin{array}{c}\text { Grupa } \\
\text { badawcza }\end{array}$ & 151,37 & 195,34 & 14,10 & 26,24 & 2,73 & 2,95 \\
\hline $\begin{array}{c}\text { Grupa } \\
\text { kontrolna }\end{array}$ & 160,08 & 233,79 & 58,63 & 72,81 & 2,7 & 3,73 \\
\hline
\end{tabular}

testach - zarówno teście DLD, DLF, jak i teście DLI - osiągnęła wyniki lepsze niż grupa kontrolna. Średni próg dyskryminacji czasu trwania dźwięku w grupie badawczej jest o 28,09 ms niższy, niż w grupie kontrolnej. Średni próg dyskryminacji natężenia dźwięku jest w grupie kontrolnej wyższy o 0,46 dB niż w grupie badawczej. Największą różnicę uzyskano w teście dyskryminacji wysokości dźwięku. W tym wypadku grupa badawcza osiągnęła znacznie lepsze wyniki niż grupa kontrolna. Średni wynik badania DLF w grupie badawczej jest o 46,17 Hz lepszy, niż w grupie kontrolnej.

W Tabeli 2 przedstawiono średnie wyniki testów DLD, DLI i DLF osiągnięte przez kobiety i mężczyzn z grupy badawczej i kontrolnej. Kobiety osiągają w teście DLD znacznie lepsze wyniki niż mężczyźni. Najniższy próg dyskryminacji czasu trwania dźwięku uzyskały kobiety z grupy badawczej (151,37 ms). Kobiety z grupy kontrolnej uzyskały wynik znacznie lepszy niż mężczyźni z grupy badawczej. Różnica wynosi 35,26 ms. Najsłabszy wynik osiągnęli mężczyźni z grupy kontrolnej - 233,79 ms. Zarówno kobiety, jak i mężczyźni z grupy badawczej uzyskali dużo lepsze wyniki niż kobiety i mężczyźni z grupy kontrolnej. Najlepszy wynik osiągają kobiety z grupy badawczej - 14,10 Hz. Najlepsze wyniki w badaniu DLI uzyskały kobiety z grupy kontrolnej. Wynik wyższy o 0,03 dB uzyskały kobiety $\mathrm{z}$ grupy badawczej. Nieco większy próg dyskryminacji natężenia dźwięku otrzymali mężczyźni z grupy badawczej. Najsłabszy wynik w badaniu DLI uzyskali mężczyźni $z$ grupy kontrolnej.

\section{Podsumowanie}

Lepsze wyniki uzyskane w testach oceniających umiejętności przetwarzania dźwięków przez osoby śpiewające $\mathrm{w}$ chórze $\mathrm{w}$ porównaniu $\mathrm{z}$ osobami nie śpiewającymi w chórze, wskazują na znaczący wpływ aktywności muzycznej, w tym przypadku śpiewania w chórze, na możliwości percepcji dźwięków. Z pewnością należy popierać takie formy aktywności, widząc w nich nie tylko korzyści estetyczne, emocjonalne i społeczne. W szczególności proponować należy śpiew chóralny jako formę edukacji dzieci i młodzieży, co może mieć wpływ na rozwój sprawności słuchowych istotnych również $\mathrm{w}$ innych sferach aktywności uczniów.

\section{Piśmiennictwo:}

1. Bonilha A.G., Onofre F., Vieira M.L. i wsp.: Effects of singing classes on pulmonary function and quality of life of COPD patients. Int J Chron Obstruct Pulmon Dis, 2009; 4: 1-8

2. Bukowska A.: Od emocji po fizjologię, czyli o oddziaływaniu muzyki na organizm człowieka, http://arteterapia.pl/artykuly/od-emocji-po-fizjologie-czyli-o-oddzialywaniu-muzyki-naorganizm-czlowieka/ (18.10.2010), 2010

3. Gulińska-Grzeluszka D.: Muzyka w aspekcie zdrowia i jakości życia pacjenta geriatrycznego. Poznańskie Zeszyty Humanistyczne X. Czabański A. (red.). Wydawnictwo Rys. Poznań, 2008
4. Kreutz G., Bongard S., Rohrmann S. i wsp.: Effects of choir singing or listening on secretory immunoglobulin A, cortisol, and emotional state. J Behav Med., 2004; 27(6): 623-35

5. Krukow P.: Muzyka i mózg, http://www.racjonalista.pl/ $k k . p h p / s, 2550$ (20.10.2010), 2003

6. Tomatis A.: Ucho i śpiew. Wydawnictwo Uniwersytetu Marii Curie-Skłodowskiej, Lublin, 1995

7. Wierszyłowski J.: Zarys psychologii muzyki. Warszawa: PWN, 1968 